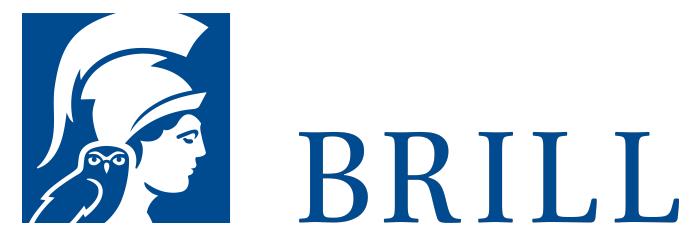

\title{
Trio, Quartett, Quintett
}

Studien zur Faktur von Mozarts später Streicher-Kammermusik

Author: Veronika Giglberger

Mozart hat sich sein Leben lang mit Kammermusik beschäftigt, einer Musik für einen Kreis von Kennern, die die hohe Qualität und "Compositionswis-senschaft" in den Werken zu schätzen wissen, und vor denen er seine her-ausragende Begabung unter Beweis stellen wollte. Die Expansion, die die Einzelstimme in Mozarts einzigem Streichtrio erfährt, übertrifft die rein aus satztechnischen Zwängen gebotene bei Weitem. Aus-gehend von diesem Schlüsselwerk (1788), das ein Experimentierfeld für neuartige und gewagte, lebhaft kon-zertierende und dialogisierende Textu-ren mit drei völlig gleichberechtigten Partnern ist, werden in der Studie die dem Trio folgenden späten kammer-musikalischen Hauptwerke, drei Streichquartette und zwei Streichquin-tette vor allem hinsichtlich ihrer Faktur untersucht. Es zeigt sich, wie Mozart eine unglaubliche Vielfalt von Gestal-tungsweisen entwickelt, zugleich ein-zelne Sätze wie auch Werke unterein-ander zyklisch verknüpft.

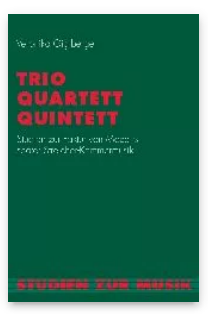

Pages: 282

Seiten

Language:

German

Subjects:

General, Musicology

Publisher: Brill |

Fink

Series:

Studien zur

Musik, Volume:

17

E-Book (PDF)

Released online:

og Dec 2019

ISBN: 978-3-

$8467-4435-2$

List price

USD \$ $\$ 68.00$

Paperback

Publication date:

23 May 2007

ISBN: $978-3^{-}$

7705-4435-6

List price

USD $\$ 68.00$ 
For more information see brill.com

Order information: Order online at brill.com +44330 333 0049 | customerservices@brill.com Submission information: brill.com/authors

Titles published by Brill | Fink, Brill | mentis or Brill | Schöningh: +49(o)715413279216| brill@brocom.de 